\title{
Canine visceral leishmaniasis in riverside communities of the Cuiabá river watershed
}

\section{Leishmaniose Visceral canina em comunidades ribeirinhas da bacia do rio Cuiabá}

\author{
Valéria Régia Franco Sousa ${ }^{1 *}$; Álvaro Felipe de Lima Ruy Dias²; \\ Juliana Yuki Rodrigues ${ }^{3}$; Mariana de Medeiros Torres ${ }^{4}$; \\ Janaína Marcela Assunção Rosa Moreira²; Luciano Nakazato'; \\ Valéria Dutra $^{1}$; Arleana do Bom Parto Ferreira de Almeida ${ }^{1}$
}

\begin{abstract}
Visceral Leishmaniasis (VL) is a parasitic zoonosis expanding in Brazil. Several municipalities in the state of Mato Grosso including those on the river Cuiabá have reported the incidence of both human and canine cases and the identification of sandfly vector, Lutzomyia longipalpis and Lu. cruzi. Dogs are considered the main reservoir of Leishmania chagasi in the urban areas, hence, we devised a crosssectional study aimed at assessing the prevalence of the infection in the dogs of riverside communities on Cuiabá River watershed by parasitological (parasitic isolation in culture), serological, and molecular methods. Of the 248 surveyed dogs, 24 were positive in enzyme linked immunosorbent assay (ELISA) or immunofluorescence antibody test (IFAT), with a prevalence of $9.7 \%$. The riverside communities located in the town of Santo Antonio do Leverger displayed a higher prevalence of the disease than the cities of Cuiabá and Várzea Grande; however, the difference was not statistically significant ( $\mathrm{p}>$ 0.05). Dogs born in the communities had a 3.24-fold higher risk of acquiring the infection. Promastigote were isolated in the axenic culture from the bone marrow samples and intact skin. Further, DNA of Leishmania sp. was detected in the bone marrow samples, lymph nodes, leukocyte cover, and skin of only one examined dog. These samples were sequenced and they showed $99 \%$ homology to L. infantum. To conclude, we observed a higher prevalence of infection in Riverside communities of Santo Antonio do Leverger and the confirmation of autochthony in these areas justifies the surveillance actions to minimise the risk of transmission within the riverine community itself, besides its dissemination to other areas by tourism.
\end{abstract}

Key words: Leishmania infantum. Riverside communities. Dog. Cuiaba.

1 Profs., Faculdade de Medicina Veterinária, FAVET, Universidade Federal de Mato Grosso, UFMT, Cuiabá, MT, Brasil. E-mail: valeriaregia27@gmail.com; lucnak@gmail.com; valeriadutra.dutra@gmail.com; arleferreira@gmail.com

2 Discentes, Programa de Pós-graduação em Ciências Veterinárias, PPGVet, UFMT, Cuiabá, MT, Brasil. E-mail: alvaro.felipe. ufmt@gmail.com; janarosavet@yahoo.com.br

3 Discente, Programa de Residência Uniprofissional em Medicina Veterinária, PRUMV, UFMT, Cuiabá, MT, Brasil. E-mail: juzinha_doll5@hotmail.com

4 Pesquisador, Secretaria Municipal de Saúde, SMS, Prefeitura Municipal de Rondonópolis, Rondonópolis, MT, Brasil. E-mail: marys_torres@hotmail.com

* Author for correspondence

Received: Nov. 29, 2018 - Approved: July, 26, 2019 


\title{
Resumo
}

\begin{abstract}
A Leishmaniose visceral é uma zoonose parasitária em expansão no Brasil. Em vários municípios do Estado de Mato Grosso têm sido notificados casos humanos e caninos, assim como a identificação de flebotomíneos vetores, Lutzomyia longipalpis e Lu. cruzi, inclusive em municípios às margens do Rio Cuiabá. Como o cão é considerado o principal reservatório da Leishmania infantum em áreas urbanas, delineou-se um estudo seccional com o objetivo de avaliar a prevalência da infecção em cães de comunidades ribeirinhas da Bacia do Rio Cuiabá por método parasitológico (isolamento parasitário em cultura), sorológico e molecular. Dos 248 cães pesquisados, 24 foram soro reagentes no ELISA ou IFI, com prevalência de 9,7\%. As comunidades ribeirinhas localizadas na cidade de Santo Antônio do Leverger apresentaram maior prevalência que as dos municípios de Cuiabá e Várzea Grande, porém não estatisticamente significativo ( $>0,05)$. Os cães nascidos nas comunidades apresentaram um risco 3,24 vezes maior de adquirir a infecção $(\mathrm{p}=0,03)$. Isolamento de promastigota em amostras de medula óssea e pele íntegra e DNA de Leishmania sp. foi detectado em amostras de medula óssea, linfonodo, capa leucocitária e pele íntegra de apenas um cão pesquisado. Tais amostras foram sequenciadas obtendo $99 \%$ de homologia a L. infantum. Em conclusão, se observou maior prevalência da infecção nas Comunidades Ribeirinhas do município de Santo Antônio do Leverger, e a comprovação de autoctonia nestas áreas justifica ações de vigilância que minimizem o risco de transmissão para a própria comunidade ribeirinha além da disseminação para outras áreas pelo turismo.
\end{abstract}

Palavras-chave: Leishmania infantum. Comunidades ribeirinhas. Cão. Cuiabá.

Visceral leishmaniasis (VL), in Brazil, is a parasitic disease caused by the protozoan Leishmania infantum, transmitted to humans, and domestic and wild animals by sandflies Lutzomyia longipalpis or Lu. cruzi (BRITO et al., 2014). The incidence of VL increases every year and more than $90 \%$ of cases occur in Brazil among the other seven countries.

Dogs serve as main reservoirs in the urban areas of Brazil. Hence, they play an important role in the epidemiology of the disease. Clinical signs of the disease may be absent in the dogs; however, several dogs exhibit systemic impairment such as lymph adenomegaly, dermatopathies, weight loss, and even chronic kidney disease. Even in asymptomatic dogs, it is essential to investigate the disease by giving high parasite cutaneous load and then assessing the risk of dissemination to vectors and other susceptible hosts (ALMEIDA et al., 2013).

Among several diagnostic methods, those used to investigate canine VL are serological tests (recommended in Brazil for surveys), molecular tests comprising of conventional PCR, nested, and real-time PCR techniques, and the parasitological, cytological, histological, and culture methods (MELÉNDEZ-LAZO et al., 2018).

In Mato Grosso, LV has been rapidly spreading after records in Várzea Grande in 1998 (MISSAWA; BORBA, 2009). Human cases, canines and sandfly surveys have been recorded in several municipalities located on the banks of the Cuiabá River (MISSAWA et al., 2010; ALMEIDA et al., 2013). In addition to the fact that riparian communities survived from fishing and tourism, they were under the direct influence of the contamination and degradation of the riverine ecotourism (GUARIM, 2005). This study is aimed at verifying the occurrence of Leishmania sp. amongst the dogs residing in the Riverside Communities of the Cuiabá River Basin, by serology, PCR and culture. In addition, the factors associated with infection were analysed along with the identification of the circulating species.

In seven riverside communities of Cuiabá River in the cities of Cuiabá (São Gonçalo Beira Rio), Várzea Grande (Bom Sucesso and Passagem da Conceição ) and Santo Antônio do Leverger (Barranco Alto, Engenho Velho, Praia do Poço and Varginha) (Figure 1), municipalities of the Cerrado 
and Pantanal Mato Grossense, 248 dogs domiciled were evaluated using a census form for serological analysis and the other factors associated with infection (viz. sex, age, breed, coat length, proximity to forest, contact, or peridomicile) were taken into account by a structured questionnaire.

Blood samples for evaluation were collected from all dogs by puncturing the cephalic or external jugular vein for serology. In $10 \%$ of the dogs that had clinical alterations compatible with VL, samples of the bone marrow, lymph node, and skin were collected for culture and PCR, to isolate and/or to detect the DNA of the parasite and to characterise the Leishmania species involved in the canine infection. These dogs were anaesthetised with ketamine-acepromazine, and local anaesthetic (lidocaine) was used for aspiration of bone marrow in the manubrium, aspiration of popliteal lymph node and cutaneous biopsy of the scapular region as well as of any cutaneous ulcers (if present).The serological techniques used were enzyme linked immunosorbent assay (ELISA) (Sensitivity 94.54\% and specificity 91.76\%)or immunofluorescence antibody test (IFAT) (Sensitivity $\geq 90 \%$ and specificity $\geq 80 \%$ ) with Bio-Manguinhos ${ }^{\circledR}$ commercial kit (FIOCRUZ, Rio de Janeiro) following the manufacturer's recommendations.

Figure 1. Riverside Communities of the Cuiabá River Watershed researched for Canine Visceral Leishmaniasis.

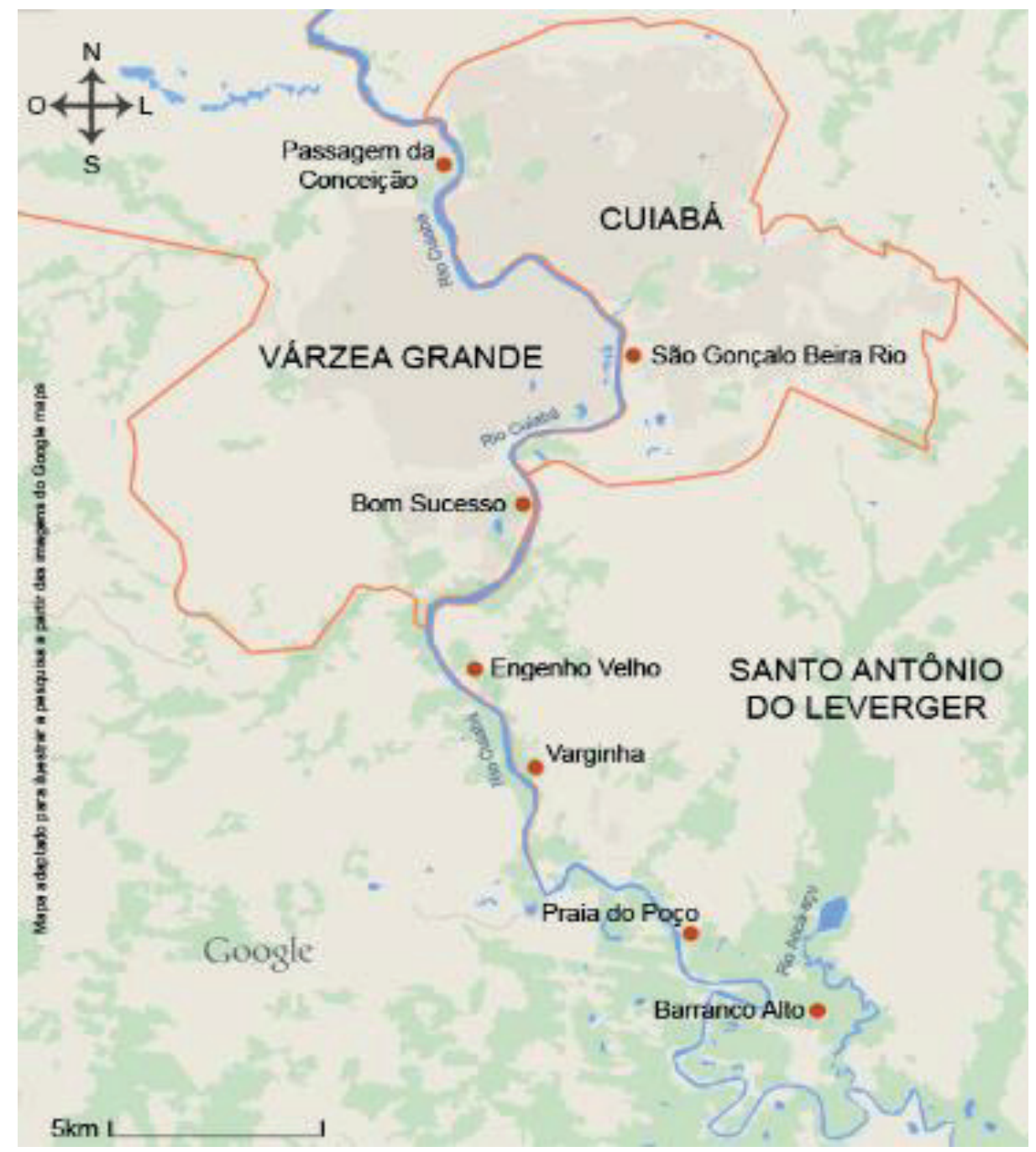

Semina: Ciências Agrárias, Londrina, v. 40, n. 6, suplemento 2, p. 3313-3320, 2019 
In the axenic culture, tissues (skin and skin ulcer), bone marrow and blood (200-300 $\mu$ l) were seeded in duplicates in a biphasic medium (NNN / Schneider) with $10 \%$ foetal bovine serum, incubated at $26-28^{\circ} \mathrm{C}$ and examined weekly for 30 days (ALMEIDA et al., 2011). Flagellated trypanosomatids isolated from the cultures were characterised by PCR and sequenced.

The DNA from the biological samples was extracted by the phenol: chloroform: isoamyl alcohol method (GOMES et al., 2007). Initially, the endogenous canine $\beta$-globin gene was evaluated from $10 \%$ of the samples by PCR to confirm the presence of DNA. Then the primers 150 [GGG(G/T)AGGGGCGTTCT(C/G)CGAA)] and $152[(\mathrm{C} / \mathrm{G})(\mathrm{C} / \mathrm{G})(\mathrm{C} / \mathrm{G})(\mathrm{A} / \mathrm{T}) \mathrm{CTAT}(\mathrm{A} / \mathrm{T})$ TTACACCAACCCC] were used to amplify 120 bp of the kDNA (minicircle) of all species of Leishmania sp. (DEGRAVE et al., 1994), and the PCR conditions used for both the analyses were as described by Almeida et al. (2013). DNA sample from L. infantum (MHOMQ / GB / 1994 / PP75) was used as positive control and ultrapure water as a negative control in all the reactions.

To further confirm the Leishmania species we carried out nested PCR of the 18S rDNA region using primers TRY927F [GAAACAAGAAACACGGGAG] and TRY927R
[CTACTGGGCAGCTTGGA] in the first step, and primers SSU561F [TGGGATAACAAAGGAGCA] andSSU561R [CTGAGACTGTAACCTCAAAGC] (SMITH et al., 2008) in the second step, followed by Sanger sequencing (Applied Biosystems ${ }^{\circledR}$ Genetic Analysis, Foster City, CA) according to the manufacturer's recommendations.

For the analysis of the variables associated with the infection rate for L. infantum, univariate analysis was performed using non-parametric chi-square $\left(\chi^{2}\right)$ or Fischer's exact test in the EpiInfo 3.3.2 program (CDC, Atlanta, USA). In the multivariate analysis, only the variables that presented a $p$ - value $\leq 0.20$ were selected, considering a significant $\mathrm{p} \leq 0.05$.

This study was approved by the Animal Ethics Committee of the Federal University of Mato Grosso (CEUA-UFMT), number 23108.014950/11-5.

Of the 248 dogs evaluated from the seven communities along the Cuiabá River, 20 (8.1\% CI 4.8-11.7) were positive in the ELISA and six (2.4\% CI $0.8-4.4 \%)$ in the IFI. Considering reagent dogs at least one test, the prevalence was $24(9.7 \%$, CI 6.0-13.7) for CVL. There was no statistically significant difference between the municipalities in the prevalence $(p>0.05)$. The number of dogs surveyed by each riparian community, as well as the prevalence is listed in Table 1.

Table 1. Prevalence of anti-Leishmania infantum antibodies in dogs of the Riverside Communities of the Cuiabá River Watershed.

\begin{tabular}{cccccc}
\hline Municipality & Riverside Communities & Canine & Positive & Prevalence (\%) & IC-95\% \\
\hline \multirow{3}{*}{ Santo Antônio de } & Barranco Alto & 50 & 7 & 14 & $(4.1-24.0)$ \\
Leverger & Engenho Velho & 37 & 6 & 16.2 & $(5.4-29.7)$ \\
& Praia do Poço & 14 & 2 & 14.3 & $(0.0-35.7)$ \\
& Varginha & 32 & 0 & 0.0 & ---- \\
\hline \multirow{2}{*}{ Várzea Grande } & Total by Municipality & $\mathbf{1 3 3}$ & $\mathbf{1 5}$ & $\mathbf{1 1 . 3}$ & $\mathbf{( 6 . 8 - 1 7 . 3 )}$ \\
& Bom Sucesso & 66 & 7 & 10.6 & $(3.0-19.7)$ \\
& Passagem da Conceição & 21 & 2 & 9.5 & $(0.0-23.8)$ \\
\hline \multirow{3}{*}{ Cuiabá } & Total by municipality & $\mathbf{8 7}$ & $\mathbf{9}$ & $\mathbf{1 0 . 3}$ & $\mathbf{( 4 . 6 - 1 6 . 1 )}$ \\
& São Gonçalo Beira Rio & 28 & 0 & 0.0 & --- \\
& Total by municipality & $\mathbf{2 8}$ & $\mathbf{0}$ & $\mathbf{0 . 0}$ & --- \\
& Grand Total & $\mathbf{2 4 8}$ & $\mathbf{2 4}$ & $\mathbf{9 . 7}$ & $\mathbf{( 6 . 0 - 1 3 . 7 )}$ \\
\hline
\end{tabular}


Among the analysed variables, the proportion of dogs evaluated / reagents was 159/14 males and $89 / 10$ females $(p=0.53)$; with ages varying from 0.5 to 16 years (median 3 years); 220/21 mixed breed and $28 / 3$ with pure breed $(\mathrm{p}=0.84)$; $226 / 21$ with short coat and 22/03 with long coat $(p=0.36)$. These variables did not show statistical significance, such as free access to the street $(\mathrm{p}=$ $0.13)$, infestation by ticks $(\mathrm{p}=0.76)$, indoor or/and outdoor $(p=0.71)$, and presence of henhouse $(p=$ $0.15)$ at the residence.

In the univariate analysis of factors related to infection, a statistically significant association was observed for the origin, $21 \mathrm{dogs}$ were positive for LVC among 174 that were born in the riverside communities ( $p=0.03$; OR 3.24 [1.2-12.4]). Another factor reported to be responsible was the observation of rodents in the domicile of 24 reactive dogs. However, none of the factors presented a significant difference when submitted for multivariate analysis.

Regarding the clinical presentation, no significant difference was observed $(p=0.16)$. Of all the dogs surveyed, 147 (59.3\%) were asymptomatic and $101(40.7 \%)$ were symptomatic. Of the 24 dogs seropositive for LVC, eleven (7.5\%) and thirteen $(12.92 \%)$ were asymptomatic and symptomatic, respectively. The major clinical signs observed in the seropositive dogs were lymphadenopathy ( $9 /$ $37.5 \%)$, dermatopathies $(3 / 12.5 \%)$, weight loss (3 / 12.5\%), ophthalmopathies ( $/ 8.3 \%)$, apathy (1 / $4.16 \%)$, and muscular atrophy (1/4.16\%).

Promastigote forms of Leishmania sp. were isolated from the bone marrow and the skin culture of one dog. DNA of Leishmania sp. was also detected in all the biological samples collected from the same canine, that after sequencing presented $99 \%$ homology with $L$. infantum. The sequence of the isolate obtained in this study was deposited with Gene Bank under accession number KT006771. This dog presented desquamation, muscular atrophy, weight loss, and apathy; resided in the community of Engenho Velho, in the municipality of Santo Antônio do Leverger eight months ago, but was born in Cuiabá.

The average prevalence observed in the communities of the three municipalities was $9.7 \%$. However, when the communities were individually analysed, three of the four evaluated in Santo Antônio do Leverger had a prevalence of over 14\%, a municipality where they have not yet published inquiries, with only human case reports years ago (HUEB et al., 1996). In Cuiabá (ALMEIDA et al., 2012) and Várzea Grande (FUJIMORI et al., 2016) cities, studies in endemic neighbourhoods showed a higher prevalence than those found. This variation in prevalence may be due to differences in the local ecosystem that interfere with the development of the vector, socioeconomic differences or the techniques employed in each study (BRUHN et al., 2018).

Despite the differences in prevalence, the demonstration of autochthony and the 3.24 times greater risk of dogs acquiring the infection in these areas, alert the risk of disease spread. Since these are the areas of tourism, tourists would be also at risk apart from the population riverside.

Among the environmental and demographic variables, presence of rodents in the domiciles of the 24 reactive dogs demonstrate the importance of rodents, especially the synanthropic ones (QUINNELL; COURTENAY, 2009). However, this information should be taken with caution owing to the intragroup differences that did not allow the statistical analysis of this variable.

Other studies have shown that those dogs inhabiting outdoors and short-haired dogs were more susceptible to infection due to increased exposure to vector. Nevertheless, such variables were not significant in the sampled dogs (COURAVITAL et al., 2013). This fact is probably due to the predominance of farms with $98.4 \%$ of the dogs living in the peridomicile and $91.1 \%$ of the dogs having short fur. 
Although not statistically significant, infected and symptomatic dogs were more easily diagnosed, similar to that observed by Fujimori et al. (2016). The major clinical signs presented at the time of clinical examination were mainly lymphadenopathy, dermatopathy, and progressive weight loss (ALMEIDA et al., 2013; FUJIMORI et al., 2016).

Leishmania DNA was amplified from the tissues of one $\operatorname{dog}$ and the isolate in the culture were sequenced to be L. infantum. As the length of stay in the community was within the incubation period of the disease, it is not possible to confirm the autochthony of this case, and this could be from the urban areas of Cuiabá, the municipality of origin.

The highest prevalence of $L$ infantum infection was observed in the Riverside Communities of the municipality of Santo Antônio de Leverger, followed by Cuiabá and Várzea Grande, and the confirmation of autochthony in these areas justifies the vigilance actions that minimise the risk of transmission to the community itself and dissemination to other areas by tourism.

\section{References}

ALMEIDA, A. B. P. F.; SOUSA, V. R. F.; BOA SORTE, E. C.; FIGUEIREDO, F. B.; PAULA, D. A. J. de; PIMENTEL, M. F. A.; DUTRA, V.; MADEIRA, M. F. Use of parasitological culture to detect Leishmania (Leishmania) chagasi in naturally infected dogs. VectorBorne and Zoonotic Diseases, Nova Iorque, v. 11, n. 12, p. 1555-1560, 2011. DOI: 10.1089/vbz.2011.0723.

ALMEIDA, A. B. P. F.; SOUSA, V. R. F.; CRUZ, F. A. C. S.; DAHROUG, M. A. A.; FIGUEIREDO, F. B.; MADEIRA, M. F. Canine visceral leishmaniasis: seroprevalence and risk factors in Cuiabá, Mato Grosso, Brazil. Revista Brasileira de Parasitologia Veterinária, Jaboticabal, v. 21, n. 4, p. 359-365, 2012. DOI: 10.1590/ S1984-29612012005000005.

ALMEIDA, A. B. P. F.; SOUSA, V. R. F.; GASPARETTO, N. D.; SILVA, G. F. R. da; FIGUEIREDO, F. B.; DUTRA, V.; NAKAZATO, L.; MADEIRA, M. F. Canine visceral leishmaniasis: diagnostic approaches based on polymerase chain reaction employing different biological samples. Diagnostic Microbiology and Infectious
Disease, Nova Iorque, v. 76, n. 3, p. 321-324, 2013. DOI: 10.1016/j.diagmicrobio.2013.03.017.

BRITO, V. N.; ALMEIDA, A. B. P. F.; NAKAZATO, L.; DUARTE, R.; SOUZA, C. O.; SOUSA, V. R. F. Phlebotomine fauna, natural infection rate and feeding habits of Lutzomyia cruzi in Jaciara, state of Mato Grosso, Brazil. Memórias do Instituto Oswaldo Cruz, Rio de Janeiro, v. 109, n. 7, p. 899-904, 2014. DOI: 10.1590/0074-027614011.

BRUHN, F. R. P.; MORAIS, M. H. F.; CARDOSO, D. L.; BRUHN, N. C. P.; FERREIRA, F.; ROCHA, C. M. B. M. Spatial and temporal relationships between human and canine visceral leishmaniases in Belo Horizonte, Minas Gerais, 2006-2013. Parasites \& Vectors, Londres, v. 11 , n. 1, p. 372-382, 2018. DOI: 10.1186/s13071-018$2877-6$.

COURA-VITAL, W.; REIS, A. B.; REIS, L. E.; BRAGA, S. L.; ROATT, B. M.; AGUIAR-SOARES, R. D.; MARQUES, M. J.; VELOSO, V. M.; CARNEIRO, M. Canine visceral leishmaniasis: incidence and risk factors for infection in a cohort study in Brazil. Veterinary Parasitology, Amsterdam, v. 197, n. 3- 4, p. 411-417, 2013. DOI: 10.1016/j.vetpar.2013.07.031.

DEGRAVE, W.; FERNANDES, O.; CAMPBELL, D.; BOZZA, M.; LOPES, U. Utilization of molecular probes and PCR for detection and typing of Leishmania - a mini-review. Memórias do Instituto Oswaldo Cruz, Rio de Janeiro, v. 89, n. 3, p. 463-469, 1994. DOI: 10.1590/ S0074-02761994000300032.

FUJIMORI, M.; ALMEIDA, A. B. P. F.; DIAS, A. F. L. R.; RODRIGUES, J. Y.; NAKAZATO, L.; MADEIRA, M. F.; SOUSA, V. R. F. Prevalence and associated factors of canine visceral leishmaniasis in na endemic area of Mato Grosso, Brazil. Acta Scientiae Veterinariae, Porto Alegre, v. 44, n. 1, p. 1424-1430, 2016. DOI: 0.22456/1679-9216.81301.

GOMES, A. H. S.; FERREIRA, I. M. R.; LIMA, M. L. S. R.; CUNHA, E. A.; GARCIA, A. S.; ARAÚJO, M. F. L.; PEREIRA-CHIOCCOLA, V. L. PCR identification of Leishmania in diagnosis and control of canine leishmaniasis. Veterinary Parasitology, Amsterdam, v. 144 , n. $3-4$, p. $234-241$, 2007. DOI: $10.1016 /$ j. vetpar.2006.10.008.

GUARIM, V. L. M. S. A educação e a sustentabilidade ambiental em comunidades Ribeirinhas de Mato Grosso, Brasil. Boletim do Museu Paraense Emílio Goeldi, sér. Ciências Humanas, Belém, v. 1, n. 1, p. 7-44, 2005.

HUEB, M.; ASSIS, S. B.; GUIMARAES, E. E. D.; ROSA, D. L.; FONTES, C. J. F. Ocorrência de transmissão autóctone de leishmaniose visceral em Mato 
Grosso. Revista da Sociedade Brasileira de Medicina Tropical, Uberaba, v. 29, n. 3, p. 281-282, 1996. DOI: 10.1590/S0037-86821996000300010.

MELÉNDEZ-LAZO, A.; ORDEIX, L.; PLANELLAS, M.; PASTOR, J.; SOLANO-GALLEGO, L. Clinicopathological findings in sick dogs naturally infected with Leishmania infantum: comparison of five differents clinical classification systems. Research in Veterinary Science, Londres, v. 117, p. 18-27, 2018. DOI: 10.1016/j.rvsc.2017.10.011.

MISSAWA, N. A.; BORBA, J. F. Leishmaniose visceral no município de Várzea Grande, estado de Mato Grosso, no período de 1998 a 2007. Revista da Sociedade Brasileira de Medicina Tropical, Uberaba, v. 42, n. 5, p. 496-502, 2009. DOI: 10.1590/S0037-86822009000500005.
MISSAWA, N. A.; MICHALSKY, E. M.; FORTESDIAS, C. L.; DIAS, E. S. Lutzomyia longipalpis naturally infected by Leishmania (L.) chagasi in Várzea Grande, Mato Grosso State, Brazil, an area of intense transmission of visceral leishmaniasis. Caderno de Saúde Pública, Rio de Janeiro, v. 26, n. 12, p. 2414-2419, 2010. DOI: 10.1590/S0102-311X2010001200020.

QUINNELL, R. J.; COURTENAY, O. Transmission, reservoir hosts and control of zoonotic visceral leishmaniasis. Parasitology, London, v. 136, n. 14, p. 1915-1934, 2009. DOI: 10.1017/S0031182009991156.

SMITH, A.; CLARK, P.; AVERIS, S.; LYMBERY, A. J.; WAYNE, A. F.; MORRIS, K. D.; THOMPSON, R. C. Trypanosomes in a declining species of threatened Australian marsupial, the brush-tailed bettong Bettongia penicillata (Marsupialia: Potoroidae). Parasitology, London, v. 135, n. 11, p. 1329-1335, 2008. DOI: 10.1017/ S0031182008004824. 
